\title{
Religious Service Attendance and Subjective Well-Being in European Countries
}

\author{
Marco Ciziceno \\ Department of Economics, Business and Statistics (SEAS) \\ University of Palermo, Italy
}

\begin{abstract}
Research findings show that endorsing a religion is to some extent related to positive health outcomes and other additional benefits linked to individuals' psychological sphere. Although an association between religion and Subjective Well-Being (SWB) has been established by previous studies, comparative investigations in the European context are limited. To fill this gap, the current research explores the possible effects of religious involvement - in the form of religious service attendance - on individuals' life satisfaction across the EU-28 countries.
\end{abstract}

Keywords: Subjective Well-Being; Life Satisfaction; Europe; Religion; Religiosity.

\section{Religion and People's Subjective Well-Being (SWB)}

Literature often associates the religious practice with numerous well-being outcomes, including the tendency to avoid unhealthy behaviours (Jones 2004; Wallace and Forman 1998), better physical health (Ellison and Leedtr 2010; Strawbridge et al. 2001), and a positive attitude towards the world (Ai et al. 2002). Furthermore, there is evidence that religion reduces psychological distress (Hahammblin and Gross 2013) since it offers people a comprehensive framework for the interpretation of human events (Ellison 1991)or serious illnesses (Hogg et al. 2010). As a result, people who define themselves as religious report higher self-esteem (Keykeyes and Reitzes 2007), have more coping skills and experience existential certainty and purpose in life (Inglehart 2010).

From another perspective, studies from Germany (Sinnewe et al. 2015), Australia (Kortt et al. 2015), United Kingdom (Lewis et al. 2005) and United States (Lim and Putnam 2010) indicate that religion grows happiness and peoples' well-being (see Diener et al. 1999). The main conclusion drawn from this body of research is that people who regularly attend religious services receive social support from their churchgoers (Ellison and George 1994), they have greater likelihoods of making new friends (Lu and Gaodu 2017; Argyle 2001) and perceive higher the quality of their relations (Bradley 1995). These results are also consistent with Durkheim's argument (1951[1897]) that religious participation increases the social integration of individuals and it lowers their probability of suicide.

However, studies mentioned above are conducted in specific areas of the world, and comparative research on this topic, especially in the EU context, is limited. To fill this gap, this research explores the possible effects of religious involvement on individuals'subjective well-being across the EU-28 countries. Results indicate that people who regularly attend religious services report higher life satisfaction (i.e., a proxy of subjective well-being) compared with infrequent attenders. This research contributes to the existing literature on subjective well-being by offering new insights about the positive association between religious involvement and people's life satisfaction in the European countries. Results and directions for future research on this topic are discussed.

\section{Research Hypothesis and Data}

The first hypothesis tested in this study is that religious affiliation (versus people not religious) is predictive of higher life satisfaction (H1). Based on previous research on this topic, the second hypothesis formulated is that people who frequently attend religious services (i.e., are more involved in their religious community) report higher life satisfaction than people who never take part in religious services (H2).Data derived from Round 7 (2014) of the European Social Survey (ESS). Data were available for the following EU-28 countries: Austria, Belgium, Czech Republic, Germany, Denmark, Spain, Finland, France, United Kingdom ${ }^{1}$, Hungary, Ireland, Lithuania, Netherlands, Poland, Portugal, Sweden, and Slovenia. The analysis involves a sample of 34633 individuals aged 14 years and over.

\section{Variables}

SWB/Life satisfaction. A single-item was used to measure people's satisfaction with their lives as a whole (Diener et al. 1999). The item was assessed by the following question: "All things considered, how satisfied are you with your life as a whole nowadays?". The item was ranging from 0 (extremely dissatisfied) to 10 (extremely satisfied). 
Religious affiliation. It was assessed by asking respondents about their religious affiliation. The item was coded by a set of categorical variables identifying Catholics (35.2\%), Protestants (13.0\%), and Other religions (6.3\%). Respondents who were not religious (45.5\%) were selected as the reference group.

Religious involvement. The item was assessed by the following question: "Apart from special occasions such as weddings and funerals, about how often do you attend religious services nowadays?". The item was measured on a seven-point scale, ranging from 1 (never) to 7 (every day).

Control Variables. A set of control variables has been included: sex $(0=$ female $; 1=$ male $)$; the age of respondents (in years); level of education attained (ES-ISCED classification); household total net income (a ten-point scale ranging from $1=$ lowest household income to $10=$ highest household income); self-reported health status (a fivepoint scale ranging from $1=$ very bad to $5=$ very good $)$ and employment status $(0=$ unemployed; $1=$ employed $)$. The country's fixed-effects have been included in the model to control for unobservable country-specific factors that may affect life satisfaction (i.e., a series of dummy variables indicating $1=$ home country of the respondent; 0 $=$ otherwise . The description of the variables used in this study is presented in Table 1 .

Table 1. Description of the variables used in the study $(N=34633)$.

\begin{tabular}{|c|c|}
\hline Variables & Description \\
\hline \multicolumn{2}{|l|}{ Dependent variable } \\
\hline Life Satisfaction & $\begin{array}{l}\text { All things considered, how satisfied are you with your life as a whole nowadays? (a ten-point scale } \\
\text { ranging from } 0=\text { extremely dissatisfied to } 10=\text { extremely satisfied) }\end{array}$ \\
\hline \multicolumn{2}{|l|}{ Religious affiliation } \\
\hline Catholic & $1=$ Catholic $; 0=$ otherwise \\
\hline Protestant & $1=$ Protestant $; 0=$ otherwise \\
\hline Other Christian religions & $1=$ Other Christian religions; $0=$ otherwise \\
\hline Not religious & Reference group \\
\hline \multicolumn{2}{|l|}{ Control variables } \\
\hline Sex & $1=$ male $; 0=$ female \\
\hline Age & Age of respondents in years \\
\hline Education & $\begin{array}{l}\text { Level of education attainted, coded as follow: } 1=\text { ES-ISCED I; } 2=\text { ES-ISCED II; } 3=\text { ES-ISCED IIIa; } 4= \\
\text { ES-ISCED IIIb; } 5=\text { ES-ISCED IV; } 6=\text { ES-ISCED V1; } 7=\text { ES-ISCED ES-ISCED V2 }\end{array}$ \\
\hline Household's income & A ten-point scale ranging from $1=$ lowest household income to $10=$ highest household income \\
\hline Subjective health status & Self-reported health status (a five-point scale ranging from $1=$ very bad to $5=$ very good) \\
\hline Employment status & $1=$ employed $; 0=$ unemployed \\
\hline Country & $1=$ home country of respondent $0=$ otherwise \\
\hline \multicolumn{2}{|l|}{ Religious involvement } \\
\hline Religious attendance & $\begin{array}{l}\text { Apart from special occasions such as weddings and funerals, about how often do you attend religious } \\
\text { services nowadays? (a seven-point scale ranging from } 1=\text { never to } 7=\text { every day) }\end{array}$ \\
\hline
\end{tabular}

\section{Results}

The analysis results are presented in Table 2 and refer to a sample of 34633 respondents. The individuals declaring themselves as "not religious" have been fixed as a reference group category. Results from OLS regression analysis support the (H1) and show that people who declare themselves as religious are more satisfied whit their life than not religious people (i.e., the baseline). Notably, the analysis of control variables included in the model shows that age $(b=0.62)$, level of education $(b=0.14)$, household income $(b=.177)$ and subjective health status $(b=.293)$ contribute significantly to increase peoples' life satisfaction, whereas unemployment status negative predicts subjective well-being $(\mathrm{b}=-.017)$.

As predicted, and in line with (H2), religious service attendance boosts people's life satisfaction $(b=0.70)$. In order to control for the unobserved individuals' heterogeneity, country-fixed effects have been included in the model, whit Germany as the baseline (see Fig. 1). After the robustness checks, the positive association between religious service attendance and subjective well-being remains positive and statistically significant. However, the inclusion of country fixed-effects in the model indicate that people living in North Europe (i.e., Denmark) are more satisfied with their life compared to people from the baseline (i.e., Germany), whereas it seems that living in southern (e.g., Spain and Portugal) or eastern (e.g., Lithuania, Hungary, Czech Republic) European countries is associated with lower levels of life satisfaction. 
Table 2. OLS regression model results. Life Satisfaction as response variable. $N=34633$, Adjusted $\mathbf{R}^{2}=.239$, $F(326,609), p<.001$.

\begin{tabular}{|c|c|c|c|c|}
\hline & Beta & S.E. & T-stat & Sig. \\
\hline \multicolumn{5}{|l|}{ Religious affiliation } \\
\hline Catholic & .015 & .034 & 1.996 & .046 \\
\hline Protestant & .010 & .040 & 1.557 & .119 \\
\hline Other Christian religions & -.024 & .061 & -4.167 & .000 \\
\hline Not religious & 0 & 0 & 0 & 0 \\
\hline \multicolumn{5}{|l|}{ Religious involvement } \\
\hline Religious attendance & .070 & .010 & 10.306 & .000 \\
\hline \multicolumn{5}{|l|}{ Control Variables } \\
\hline Gender & -.014 & .023 & -2.657 & .008 \\
\hline Age & .062 & .001 & 10.026 & .000 \\
\hline Education & .014 & .004 & 2.613 & .009 \\
\hline Employment status & -.017 & .027 & -2.730 & .006 \\
\hline Household income & .177 & .005 & 29.179 & .000 \\
\hline Subjective health status & .293 & .015 & 48.385 & .000 \\
\hline \multicolumn{5}{|l|}{ Country Fixed-effects } \\
\hline country__[Austria] & -.014 & .065 & -2.066 & .039 \\
\hline country_2[Belgium] & -.014 & .061 & -2.166 & .030 \\
\hline country_3[Czech Republic] & -.085 & .062 & -12.912 & .000 \\
\hline country__4[Denmark] & .064 & .065 & 10.019 & .000 \\
\hline country__5[Spain] & -.043 & .063 & -6.495 & .000 \\
\hline country_6[Finland] & .050 & .057 & 7.265 & .000 \\
\hline country__7[France] & -.107 & .059 & -15.892 & .000 \\
\hline country__8[United Kingdom] & -.036 & .057 & -5.348 & .000 \\
\hline country__9[Hungary] & -.158 & .066 & -25.039 & .000 \\
\hline country__10[Ireland] & -.083 & .061 & -11.619 & .000 \\
\hline country__11[Lithuania] & -.186 & .061 & -26.613 & .000 \\
\hline country__12[Netherlands] & .013 & .059 & 2.015 & .044 \\
\hline country__13[Poland] & -.059 & .070 & -8.762 & .000 \\
\hline country_14[Portugal] & -.125 & .071 & -19.571 & .000 \\
\hline country__15[Sweden] & .022 & .060 & 3.303 & .001 \\
\hline country__16[Slovenia] & -.064 & .072 & -10.383 & .000 \\
\hline country__17 [Germany] & 0 & 0 & 0 & 0 \\
\hline (Constant) & 3.449 & .086 & 39.970 & .000 \\
\hline
\end{tabular}

Fig. 1 Predicted levels of Life Satisfaction among Europe (Germany as baseline).

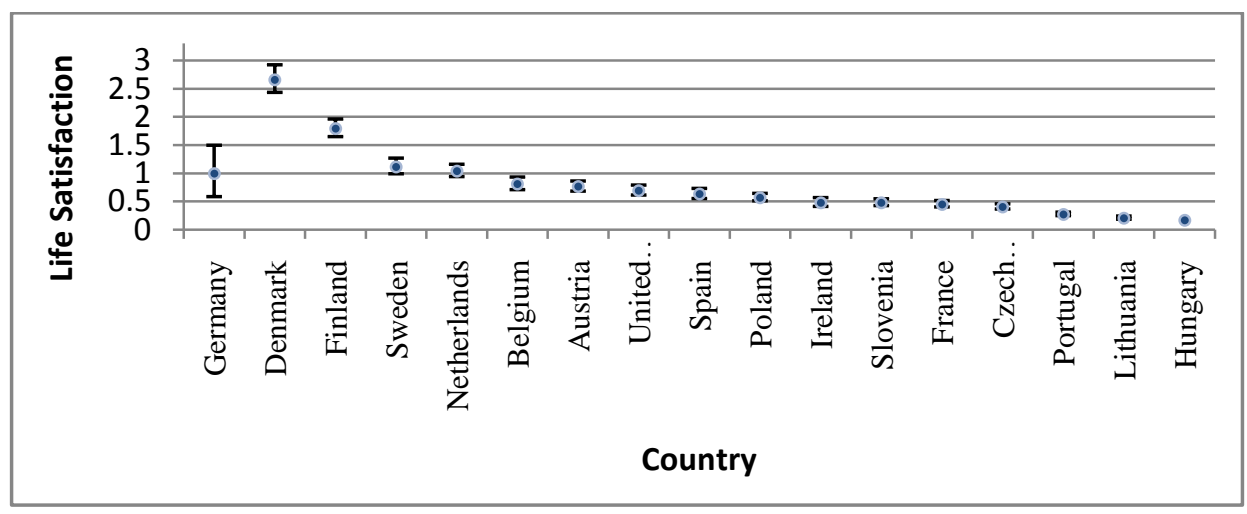




\section{Discussion and Conclusions}

This research shows that people who frequently attend religious services express higher satisfaction with their life, indicating a positive association between religious service attendance and subjective well-being. The country-fixed effects included in the analysis have also revealed that this association is robust across the EU-28 countries. In support of this finding, Ferriss (2002) has found that religious group members were happier than those without any religious affiliation. According to Stavrova et al. (2013), the happiness of religious attenders is, in part, explained by the benefit derived them from the church social support. Such social support represents a fertile ground for people's well-being and their psychological sphere. For example, Ellison (1991) has found that regular churchgoers draw comfort from their congregation members, they experience a fewer sense of loneliness, and report lower suicide rates (Stack and Wasserman 1992; Martin 1984; see also Durkheim 1951[1897]). In line with this finding, Lim and Putnam (2010) have found that people involved in a religious group are more satisfied with their life than not religious people because they build social ties within their religious community, which boosts their sense of well-being. Jung (2014) demonstrated that in South Korea, women church attenders tend to report greater happiness and lower levels of stress.

Finally, by introducing the country fixed-effects in the model, results indicated higher levels of life satisfaction in people from Denmark and Finland, rather than in those from other parts of Europe (e.g., southern and eastern countries). Frey and Stutzer (2002) have demonstrated that either the economic variables (i.e., income, unemployment rates) or the institutional factors, in the form of well-functioning institutional systems, positively influence peoples' well-being because they ensure more stable and predictable living conditions. Ciziceno and Pizzuto (2020) drawn to similar results investigating the well-being gap in European countries after the Great Recession.

This study provides convincing evidence that religious involvement promotes peoples' well-being in the European context. However, some aspects surrounding this association need to be further investigated. For example, results established in this paper have demonstrated a positive association with life satisfaction only in the case of church service attendance. Directions for further research could include investigations about the effects of other religious forms (e.g., prayer) on peoples' life satisfaction and perceived well-being.

\section{References}

Ai, A. L., Peterson, C., Bolling, S. F., \&Koenig, H. (2002). Private prayer and optimism in middle-aged and older patients awaiting cardiac surgery. The Gerontologist, 42(1), 70-81.

Argyle, M. (2001). The psychology of happiness (2nd ed.) New York: Routledge.

Bradley, E. (1995). Religious involvement and social resources: evidence from the data set Americans' changing lives. Journal for the Scientific Study of Religion, 259-267.

Ciziceno, M., \& Pizzuto, P. (2020). The Well-Being Gap during the Great Recession: The Role of Growth and Institutions. Research in Applied Economics, 12 (2). doi: 10.5296/rae.v12i2.16728

Diener, E., Suh, E. M., Lucas, R. E., \& Smith, H. L. (1999). Subjective well-being three decades of progress. Psychological Bulletin, 125(2), 276-302.

Durkheim, E. (1951). Suicide: a study in sociology [1897]. Translated by J.A. Spaulding and G. Simpson (Glencoe, Illinois: The Free Press, 1951).

Ellison, C. G. (1991). Religious involvement and subjective well-being. Journal of Health and Social Behavior, 8099.

Ellison, C. G., \& George, L. K. (1994). Religious involvement, social ties, and social support in a southeastern community. Journal for the Scientific Study of Religion, 33(1), 46-61. doi:10.2307/1386636

Ellison, C. G., \& Lee, J. (2010). Spiritual struggles and psychological distress: is there a dark side of religion?. Social Indicators Research, 98(3), 501-517.

Ferriss, A. L. (2002). Religion and the quality of life. Journal of Happiness Studies, 3(3), 199-215.

Frey, B. S., \&Stutzer, A. (2002). What can economists learn from happiness research?. Journal of Economic Literature, 40(2), 402-435.

Hamblin, R., \& Gross, A. M. (2013). Role of religious attendance and identity conflict in psychological well-being. Journal of Religion and Health, 52(3), 817-827.

Hogg, M. A., Adelman, J. R., \&Blagg, R. D. (2010). Religion in the face of uncertainty: An uncertainty-identity theory account of religiousness. Personality and Social Psychology Review, 14(1), 72-83.

Inglehart, R. (2010). Faith and freedom: Traditional and modern ways to happiness. In E. Diener, J.F. Helliwell, D. Kahneman (Ed.), International differences in well-being (pp. 351-397). Oxford: Oxford University Press.

Jones, J. W. (2004). Religion, health, and the psychology of religion: How the research on religion and health helps us understand religion. Journal of Religion and Health, 43(4), 317-328.

Jung, J. H. (2014). Religious attendance, stress, and happiness in South Korea: Do gender and religious affiliation matter?. Social Indicators Research, 118(3), 1125-1145. 
Keyes, C. L., \&Reitzes, D. C. (2007). The role of religious identity in the mental health of older working and retired adults. Aging and Mental Health, 11(4), 434-443.

Kortt, M. A., Dollery, B., \& Grant, B. (2015). Religion and life satisfaction down under. Journal of Happiness Studies, 16(2), 277-293.

Lewis, C. A., Maltby, J., \& Day, L. (2005). Religious orientation, religious coping and happiness among UK adults. Personality and Individual differences, 38(5), 1193-1202.

Lim, C., \& Putnam, R. D. (2010). Religion, social networks, and life satisfaction. American Sociological Review, $75(6), 914-933$.

Lu, J., \& Gao, Q. (2017). Faith and Happiness in China: Roles of Religious Identity, Beliefs, and Practice. Social Indicators Research,132(1), 273-290.

Martin, W.T. (1984). Religiosity and United States Suicide Rates, 1972-1978. Journal of Clinical Psychology, 40: $1166-1169$.

Sinnewe, E., Kortt, M. A.,\&Dollery, B. (2015). Religion and life satisfaction: evidence from Germany. Social Indicators Research, 123(3), 837-855.

Stack, S., \& Wasserman, I. (1992). The Effect of Religion on Suicide Ideology: An Analysis of the Networks Perspective. Journal for the Scientific Study of Religion, 31(4), 457-66.

Stavrova, O., Fetchenhauer, D., \&Schlösser, T. (2013). Why are religious people happy? The effect of the social norm of religiosity across countries. Social Science Research, 42(1), 90-105.

Strawbridge, W. J., Shema, S. J., Cohen, R. D., \& Kaplan, G. A. (2001). Religious attendance increases survival by improving and maintaining good health behaviors, mental health, and social relationships. Annals of Behavioral Medicine, 23(1), 68-74.

Wallace Jr, J. M., \& Forman, T. A. (1998). Religion's role in promoting health and reducing risk among American youth. Health Education \& Behavior, 25(6), 721-741. 